Pécsi Tudományegyetem Klinikai Központ Fogászati és Szájsebészeti Klinika, Fogpótlástani Tanszék* Southgate Dental Ltd., Ireland**

Újvidéki Egyetem, Orvostudományi Kar, Fogorvosi Szak**

\title{
A kombinációs szindróma gyakorisága a Pécsi Tudományegyetem Klinikai Központ Fogpótlástani Tanszékén a 2009 és 2014 között készült orthopantomogramok alapján
}

\author{
DR. MARKOVICS DÓRA*, DR. SZENDI RÓBERT ${ }^{* *}$, DR. VICKO KRISTINA***, \\ DR. RAJNICS ZSOLT*, DR. MARADA GYULA*, DR. RADNAI MÁRTA*
}

\begin{abstract}
A klinikumban gyakori olyan páciensek kezelése, akiknek fogatlan a felső állcsontjuk, miközben a mandibula frontfogai megtartottak. Az ilyen esetekben sokszor láthatunk specifikus elváltozásokat, amelyeket Kelly (1972) kombinációs szindróma névvel foglalt össze.

Vizsgálatunk célja az volt, hogy felmérjük, pácienseink körében előfordult-e az elmúlt 5 évben a kombinációs szindrómára jellemző tünetegyüttes, vagy valamelyik jellegzetesség.

A PTE által használt informatikai rendszer segítségével 319 páciens nevét szűrtük ki, akiket foghiány diagnózissal rögzítettek az elmúlt 5 évben. Ezek közül 220 páciens orthopantomogram felvétele állt rendelkezésre a kombinációs szindrómára jellemző tünetek gyakoriságának vizsgálatához. 34 beteg felvételén találtunk fogatlan felső állcsontot és meglévő alsó frontfogakat. A kombinációs szindróma fő tünete, a nagyfokú csonthiány a maxilla elülső régiójában 4 esetben volt látható, ez 11,7\%-os gyakoriságot jelent. A tuber maxillae hipertrófiája (9 esetben, 26,4\%) az alsó frontfogak extrúziója (6 esetben, 17,6\%) és az alsó állcsont disztális régiójának csontlebontódása (16 esetben, 47\%) volt látható a felvételeken. A röntgenfelvételek alapján kiszűrt betegek közül három esetben került sor klinikai vizsgálatra, ami minden esetben igazolta a röntgenfelvételen látott jellegzetességeket.

A kombinációs szindróma gyakorisága saját beteganyagunkban lényegesen kisebb volt, mint más tanulmányokban, ismeretének klinikai jelentősége azonban nem elhanyagolható.
\end{abstract}

Kulcsszavak: kombinációs szindróma, csontlebontódás, tuber maxillae hipertrófia, frontfog extrúzió, implantátum

\section{Bevezetés}

A klinikumban igen gyakori olyan páciensek kezelése, akiknek felső állcsontja teljesen fogatlan és a mandibula frontfogai megtartottak [22]. Sokszor láthatunk a fent említett foghiány esetében specifikus elváltozásokat, amelyekről a magyar nyelvü fogorvosi szakirodalomban nem olvashatunk.

Ellisworth Kelly volt az első 1972-ben, aki ezen tünetekre a „kombinációs szindróma” elnevezést használta [11], a tünetegyüttes másik elnevezése az ,anterior hiperfunkciós szindróma" [10]. A fogalommal a "The Glossary of Prosthodontic Terms"-ben is találkozhatunk [26]. Kelly öt föbb elváltozást írt le, amelyek vizsgálatai szerint gyakran előfordultak az ilyen fogazati státuszú betegek esetében: (1) fogatlan állcsontgerinc lebontódása a maxilla elülső területén, (2) tuber maxillae hipertrófiája, (3) papilláris hiperplázia a keményszájpadon, (4) a mandibula frontfogainak extrúziója, valamint (5) kifejezett csontlebontódás az alsó részleges fogsor alaplemeze alatt [11]. Későbbiekben Saunders és munkatársai további hat tünetet társítottak a már leírtakhoz: (1) harapási magasság csökkenése, (2) az okklúziós sík diszkrepanciája, (3) a mandibula relatív propulziója, (4) a kivehető pótlás nem megfelelő illeszkedése, (5) granuloma fissuratum és (6) parodontális változások [21] (1. ábra).

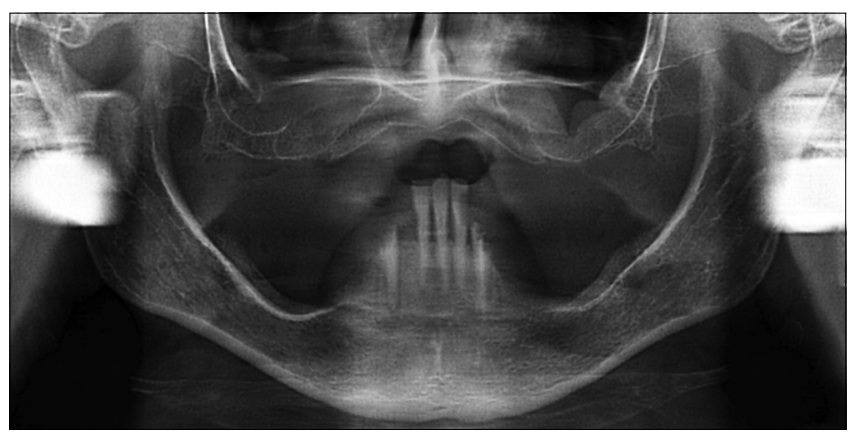

1. ábra: A kombinációs szindróma típusos esete az OPT felvételen. A maxilla frontrégiójának kraniálisan ív alakú csonthiánya, a tuberek hipertrófiája, a mandibula frontfogainak extrúziója, valamint a disztális régió csonthiánya látható. 


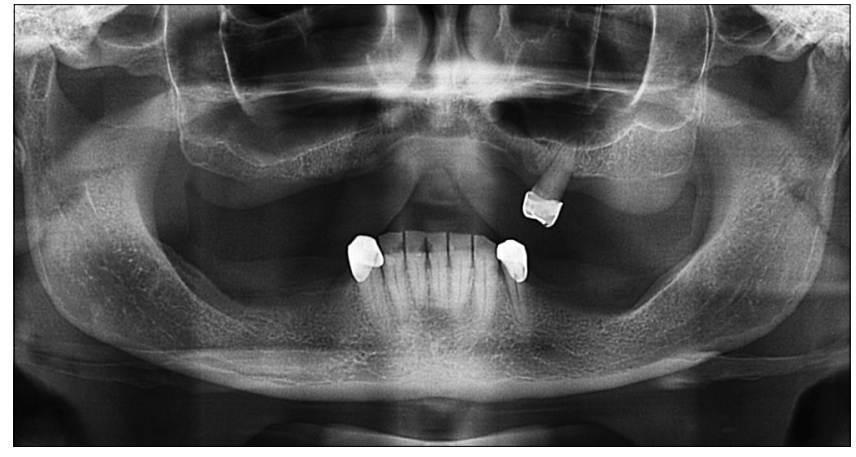

2. ábra: Az OPT felvétel mutatja a felső őrlőfog szupra-erupciós helyzetét, valamint a frontrégió kraniálisan ív alakú csonthiányát és a tuberek hipertrófiáját.

A megfigyelt elváltozások kialakulását többféleképpen magyarázták. Len Tolstunov elmélete szerint az őrlőfogak hiánya a disztális régióban hipofunkciót eredményez, ennek következtében a hatékony rágás érdekében a rágási funkció a frontális területre tevődik át és a mandibula elülső területén a csontállomány vertikális irányban növekszik [27]. A meglévő, esetleg elongálódott alsó metszők folyamatos nyomást gyakorolnak a felső teljes protézisre a maxilla elülső, fogak által alá nem támasztott területén. Ez a folyamatos lokális terhelés okozza a csontlebontódást a maxilla elülső területén [10, 27].

A kétoldali tuber maxillae növekedését, hipertrófiáját eredeti cikkében Kelly a teljes lemezes fogsor alatti „negatív nyomással” magyarázta [11]. Azonban manapság ezt az elváltozást nem a negatív nyomásnak tulajdonítják, hanem úgy vélik, hogy a mandibula disztális régiójának lassú lebontódása, az alveolaris gerinc magasságának csökkenése, valamint a részleges fogsor folyamatos süllyedése okozza. Amennyiben egy vagy néhány őrlőfog a felső állcsonton megtartott, úgy ezen fogak szupra-erupciója (2. ábra) is megfigyelhető [27].

Sok esetben elmarad a kivehető lemezes pótlás átadását követő rendszeres kontrollvizsgálat. A pácienseknek a viselés során lassan kialakuló elváltozások sokszor nem okoznak panaszt, nem zavarják lényegesen a funkciót, a pótlás sokszor ezek ellenére kényelmes. A problémák észrevétlenek maradnak a beteg számára, aki nem érzi a kontrollvizsgálat szükségességét. A mandibula frontfogainak incizális éle által kiváltott krónikus okkluzális trauma gyakran okoz lötyögő, fibrotikus lágyszövet-elváltozásokat a palatum elülső területén, melyet gyakran papilláris hiperpláziaként említ az irodalom [11, 19, 23].

Amennyiben a hiányzó fogakat nem pótolják, akkor az antagonista fogak extrúziója következhet be [18]. Kiliaridis és munkatársai szerint az antagonista nélkül maradt fogak $82 \%$-ában fordul elő szupra-erupció [12], aminek oka a fogak okkluzális megtámasztottságának hiánya.

Mind a maxilla elülső, mind pedig a mandibula hátsó régiójában a fogatlan gerinc reszorpciójának következtében csökken a harapási magasság. A mandibula sokszor propulziós helyzetbe kerül [27], aminek következménye szintén a felső lemezes pótlás frontális részének süllyedése.

A szindróma legfontosabb tünete az állcsontgerinc lokális reszorpciója, vagyis lötyögő, csontmag nélküli gerinc [6] kialakulása, ami megnehezítheti a teljes felső múfogsor viselését vagy új fogsor készítését is, hiszen a lenyomatvételt speciális módszerrel kell kivitelezni [17].

Vizsgálatunk célja az volt, hogy a Pécsi Tudományegyetem Fogászati és Szájsebészeti Klinikáján felmérjük, hogy a Fogpótlástani Tanszéken megjelent betegek körében előfordult-e az elmúlt 5 évben a kombinációs szindrómára jellemző tünetegyüttes, vagy azok közül valamelyik jellegzetesség.

\section{Anyag és módszer}

A Pécsi Tudományegyetem által használt e-MedSolution egészségügyi informatikai rendszer segítségével a járóbetegek közül kiválasztottuk azokat, akiket foghiány diagnózissal, a K0000 BNO kóddal rögzítettek az előző 5 évben, 2009 és 2014 között. A program 319 páciens nevét szűrte ki. Következő lépés az orthopantomogram (OPT) felvételek kikeresése volt. Összesen 220 betegről készült OPT felvétel. A digitális panoráma röntgenek alapján kiválasztottuk azokat a pácienseket, akiknek a fogazati státusza megfelelt a vizsgálat feltételeinek, vagyis a felsó állcsont teljesen fogatlan volt és az alsó frontfogak megtartottak voltak. Összesen 34 beteg teljesítette a fenti kritériumot. Ezeken a röntgeneken vizsgáltuk a kombinációs szindróma egyes tüneteinek előfordulását. A csonthiány a maxilla elülső területén, a tuber maxillae hipertrófiája, az alsó frontfogak extrúziója és az alsó állcsont disztális régiójának csontlebontódása volt értékelhető a felvételeken.

Azokat a betegeket, akiknek a röntgenfelvételén a szindróma legjellegzetesebb tünetét diagnosztizáltuk, berendeltük (4 személy), hogy megvizsgáljuk a fogatlan gerincek formáját, a nyálkahártya esetleges elváltozásait és a fogsorok okklúzióját. A betegek klinikai vizsgálata három esetben valósult meg, anamnézis felvétel, klinikai vizsgálat, anatómiai lenyomatvétel és fotódokumentáció készült.

\section{Eredmények}

A 220 páciens felvételének vizsgálata során 34 beteg fogazati státusza felelt meg a követelményeknek, vagyis a fogatlan maxillával szemben a mandibulában 6-8 fog volt a frontrégióban. Az orthopanthomogram felvételek értékelése alapján a kombinációs szindróma fő tünete, a maxilla frontrégiójában előforduló kifejezett állcsontgerinc reszorpciója 34 beteg közül 4 esetben (11,7\%-os 
gyakoriság) volt látható. A többi tünet közül a tuber maxillae hipertrófiája (9 esetben, 26,4\%), az alsó frontfogak extrúziója ( 6 esetben, 17,6\%) és a csontlebontódás az alsó állcsont disztális régiójában (16 esetben, $47 \%$ ) volt egyértelmú a felvételeken.

$A$ berendelt betegek közül hárman jelentek meg. Az első megjelent páciens esetén a korábbi OPT felvétel alapján jól látható volt a gerinc nagyfokú atrófiája a felső frontális területen, a tuber maxillaek hipertrófiája, a frontfogak extrúziója, valamint a gerinc csontlebontódása a mandibula moláris régiójában (1. ábra). A beteg 3 évvel régebbi OPT felvétele óta eltávolításra kerültek alsó frontfogai. Az intraorális vizsgálat eredménye: lötyögő, csontmag nélküli gerinc a maxilla frontális régiójában, a tuberek hipertrófiája és a mandibula disztális gerincének csontlebontódása.

A második páciensnek előző megjelenése óta eltávolításra került a bal felső második moláris foga, így megfelelt a követelményeknek. A korábbi és az új digitális OPT felvételen három tünet volt felismerhető: a kifejezett csontreszorpció a maxilla front régiójában, a tuberek hipertrófiája, valamint a mandibula disztális gerincének fokozott lebontódása. Az intraorális vizsgálat során a tuberek hipertrófiája és a mandibula csontlebontódása jól látható volt, azonban a felső front régió csonthiánya és a frontfogak extrúziója nem volt jelentős (3., 4. ábra).

Harmadik páciensünk státusza nem változott utolsó

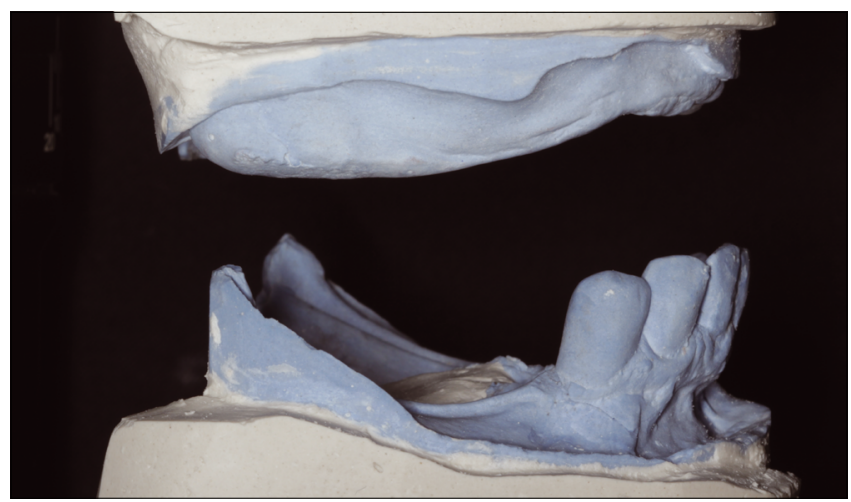

3. ábra: A gipszmintákon megfigyelhető a tuber maxillae hipertrófiája, valamint a csontlebontódás a mandibula disztális régiójában.

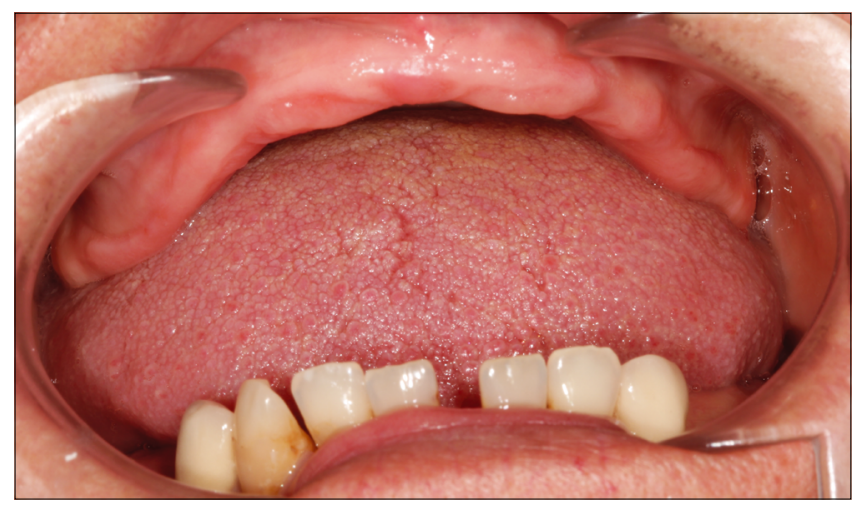

4. ábra: A kombinációs szindrómára jellemző fogazati státusz: a fogatlan maxillával szemben a mandibula frontfogai megtartottak. megjelenése óta. A korábbi és az új OPT felvételén a maxilla frontrégiójának, a mandibula disztális régiójának csontvesztesége jól látható volt, azonban a tuberek hipertófiája nem volt kifejezett, az alsó frontfogak nem elongálódtak. A szájvizsgálat igazolta a felső frontrégió csonthiányát, a tuber hipertrófiát, valamint a mandibulában a disztális gerinc kifejezett sorvadását. A páciens emlékezete szerint 6 éve viselte a felső teljes és az alsó részleges kivehető fogpótlást.

Egyik esetben sem diagnosztizáltunk papillaris hiperpláziát.

\section{Megbeszélés}

A kombinációs szindróma egyes tüneteinek gyakorisága saját beteganyagunkban lényegesen kisebb volt, mint más vizsgálatokban.

Shen és munkatársai 150 olyan beteg vizsgálata alapján, akiknek teljes felső protézisük volt és ezzel szemben az alsó fogívben az elülső és/vagy oldalsó régióban voltak saját fogak, a következőket találta: a kombinációs szindróma mind az öt tünete az összes beteg közül 7\%-ban fordult elő, viszont 24\%-ban azoknál, akik az alsó állcsonton a kétoldali sorvégi foghiány pótlására részleges kivehető múfogsort viseltek [23].

Szintén teljes felső fogsor alatti csontreszorpciót találtak Bergman és munkatársai olyan betegek esetében, akiknek csak elülső fogaik voltak az alsó állcsontban, de a vizsgált csoportban nagy egyéni különbségek mutatkoztak. A kombinációs szindróma kialakulására azonban nem találtak bizonyítékot [3].

Lechner és Mammen kifejezett frontális csontfelszívódást a maxillán, a felső fogsor retenciójának csökkenését, a rágófogak közötti okklúzió megszűnését és nagyobb terhelést találtak 13 beteg vizsgálatakor, akik legalább három évig teljes felső fogsort és két implantátumon megtámasztott alsó protézis viseltek [16]. Más kutatók ugyan nem találtak szignifikánsan nagyobb csontreszorpciót hasonló státusszal rendelkező betegek vizsgálata során, de beteganyagukban a tendencia a fokozott maxilláris csontlebontódásra kimutatható volt $[8,15,28]$. A reszorpciós folyamatokat ugyanis több tényező is befolyásolja. Ezek a korábban végzett extrakciók, a régi fogpótlások minősége, ha viselt a beteg régebben pótlást, parafunkciós tényezők, valamint szisztémás betegségek (diabetes, osteoporosis) [24]. A legnagyobb problémát a parafunkciós szokások (szorítás, őrlés) jelentik [25]. Tallgren és munkatársainak követéses kutatásai azt mutatták, hogy a fogatlan páciensek esetében a fogsorviselés első évében a gerinc a mandibulában átlagosan négyszer gyorsabban bontódik le, mint a maxilában, mivel a mandibula teherviselő felszíne jóval kisebb, a fogatlan gerinc formája kevésbé előnyös, valamint nincs másodlagos teherviselő felszín, mint a maxilla esetén a palatum. A legnagyobb csontlebontódás mindkét állcsont esetén a fogeltávolítások utáni első évben következik be [25]. Számos ta- 
nulmány írja le az immediát fogpótlások és az overdenture pótlások előnyeit, mivel a müfogsor viselése lassítja a csontlebontódást; a megfelelő okklúziós viszonyok kialakítása csökkenti a frontális régió terhelését [21, 27].

Áttekintő cikkükben Palmqvist és munkatársai [19], valamint Rutkunas és munkatársai [20] a rendelkezésre álló publikációk áttanulmányozásával arra a következtetésre jutottak, hogy a Kelly által felsorolt tünetek nem tekinthetők orvosi értelemben szindrómának, bár egyes tünetek fellelhetők a betegekben, és nem találták bizonyítottnak, hogy az alsó frontfogak jelenléte csontlebontódást okozna a fogatlan maxilla frontrégiójában.

Ha a kombinációs szindróma minden tünete nincs is jelen nagy gyakorisággal, a maxilla elülső területén esetleg kialakuló fokozott csontlebontódás lehetősége fontossá válhat napjainkban, amikor a mandibulában két implantátum beültetése és erre hibridfogsor készítése egyre gyakoribbá válik $[7,8]$. Mivel a felső teljes protézisek retenciója általában jobb, mint az alsó teljes fogsoré, a betegek sokszor továbbra is ilyen pótlást viselnek. Az alsó teljes protézis stabilizálása érdekében az implantátumokat rendszerint interforaminálisan ültetik be, tehát az ezekre készülő fogsorok főleg a frontrégióban képeznek nagyobb terhelést a velük szemben lévő múfogsorra, illetve azon keresztül a felső állcsontra [5], ezért a szindróma kialakulásának esélye ilyen esetekben is megvan.

Lötyögő, csontmag nélküli gerinc névvel az állcsontgerinc felszívódása utáni kialakuló kötőszövetes hiperpláziát jelöljük [6], ami gyakorlatilag azonos jelenség a kombinációs szindróma legfontosabb tünetével és a klinikai tapasztalatok szerint $10-20 \%$-ban fordulhat elő [4]. Bárhogyan is nevezzük, a jelenség nem kívánatos, ezért az esetleges fokozott csontlebontódás megelőzése érdekében fontos a fogpótlások megfelelő okklúziójának kialakítása, vagyis az alsó és a felső metszőfogak érintkezésének elkerülése az overbite és az overjet fenntartásával [1, 9]. A szerzők különféle módszereket ajánlanak a megfelelő okklúziós viszonyok kialakítására és fenntartására kombinációs szindróma esetében, így például fém rágófelszínt [14], vagy öntött fém múfogakat lehet alkalmazni a rágófogrégióban [22]. Ezek a módszerek a megelőzésben és a terápiában is szerepet játszhatnak, mivel csökkentik a frontrégióban a gerincre jutó rágónyomást és fenntartják az optimális harapási magasságot.

Mivel implantátumok esetében nem kell tartani azok kiemelkedésétől, az alsó és felső frontfogak között a fogfelállításkor kialakított távolság hosszú időn át fenntartható, ezáltal biztosítható, hogy a terhelés a rágófogak régiójában koncentrálódjon. Ennek ellenőrzése, és föként az alsó állcsontgerinc lebontódásának kompenzálására az alsó részleges vagy hibridfogsor, akár természetes fogakon, akár implantátumokon van megtámasztva/ elhorgonyozva, rendszeres ellenőrzése és alábélelése elengedhetetlen.

Természetesen, ha a kockázati tényezőt jelentő előnytelen fogazati státuszt (felső teljes fogatlanság, alsó meg- tartott frontfogak) megszüntetjük implantátumok beültetésével a rágófogak régiójában vagy a felső állcsontban és a disztális támasztózónákat helyreállítjuk, akkor a legkorszerübb módon előzzük meg a kombinációs szindróma esetleges kialakulását [2].

A szindróma ismerete a fentiek alapján a klinikai gyakorlatban igen fontos. Betegeink kezelésekor gondolni kell kialakulásának megelőzésére, vagy ha már egyes tünetek létrejöttek, akkor azok további súlyosbodásának elkerülésére.

\section{Irodalom}

1. Ahmad F, N. Yunus, F McCord: A New Presentation of Combination Syndrome. Annal Dent UnivMalaya 2008; 15: 94-99.

2. Bedrossian E, Sullivan RM, Fortin Y, Malo P, Indresano T: FixedProsthetic Implant Restoration of the Edentulous Maxilla: A Systematic Pretreatment Evaluation Method. J Oral Maxillofac Surg 2008; 66: 112-122.

3. Bergman B, Carlsson GE: J Clinical long-term study of complete denture wearers. Prosthet Dent 1985; 53: 56-61.

4. Budtz-Jørgensen E: Oral mucosal lesions associated with the wearing of removable dentures. J Oral Pathol 1981; 10: 65-80.

5. Dantas Ide S, Souza MB, Morais MH, Carreiro Ada F, Barbosa Ga: Success and survival rates of mandibular overdentures supported by two or four implants: a systematic review. Braz Oral Res 2014; 28: 74-80.

6. FÁbIÁn T, Götz Gy, KaÁn M, Szabó I: A fogpótlástan alapjai, 2. kiadás. Semmelweis Kiadó, Budapest, 2001; 329.

7. Jacobs R, Schotte A, van Steenberghe D, Quirynen M, Naert I: Posterior jaw bone resorption in osseointegrated implant-supported overdentures. Clin Oral Implants Res. 1992; 3: 63-70.

8. Jacobs R, van Steenberghe D, Nys M, Naert I: Maxillary bone resorption in patients with mandibular implant-supported overdentures or fixed prostheses. J Prosthet Dent 1993; 70: 135-140.

9. JAMESON WS: The use of linear occlusion to treat a patient with combination syndrome: a clinical report. J Prosthet Dent 2001; 85: 15-19.

10. JAMESON WS: Combining fixed and removable restorations with linear occlusion to treat combination syndrome: a clinical report. Gen Dent 2004; 52: 135-141.

11. KeLLy E: Changes caused by a mandibular removable partial denture opposing a maxillary complete denture. J Prosthet Dent 1972; 27: 140-150.

12. Kiliaridis S, Lyka I, Friede H, Carlsson GE, Ahlowist M: Vertical position, rotation, and tipping of molars without antagonists. Int $J$ Prosthodont 2000; 13: 480-486.

13. Kilicarslan M, Akaltan F, Kasko Y, Kocabas Z: Clinical evaluation of maxillary edentulous patients to determine the prevalence and oral risk factors of combination syndrome. Journal of Dental Sciences 2014; 9: 394-399

14. KOPER A: The maxillary complete denture opposing natural teeth: problems and some solutions. J Prosthet Dent 1987; 57: 704-707.

15. Kreisler MI, Behneke N, Behneke A, d'Hoedt B: Residual ridge resorption in the edentulous maxilla in patients with implant-supported mandibular overdentures: an 8-year retrospective study. Int J Prosthodont 2003; 16: 295-300.

16. LeChner SK, Mammen A: Combination syndrome in relation to osseointegrated implant-supported overdentures: a survey. Int J Prosthodont 1996; 9: 58-64.

17. LYNCH CD, ALLEN PF: Management of the flabby ridge: using contemporary materials to solve an old problem. Br Dent J 2006; 200: 258-261.

18. Matsuda K, Miyashita Y, Ikebe K, Enoki K, Kurushima Y, Mihara Y, MAEDA Y: Overeruption of teeth opposing removable partial dentures: a preliminary study. Int J Prosthodont 2014; 27: 475-476. 
19. Palmovist S, Carlsson G: The combination syndrome: a literature review. J Prosthet Dent 2003; 90: 270-275.

20. Rutkunas VI, Mizutani H, Peciuliene V, Bendinskaite R, Linkevicius $T$ : Maxillary complete denture outcome with two-implant supported mandibular overdentures. A systematic review. Stomatologija 2008; 10: 10-15.

21. Saunders T, Gillis Jr R, Desjardins R: The maxillary complete denture opposing the mandibular bilateral distal-extension partial denture: treatment considerations. J Prosthet Dent 1979; 1: 124-128.

22. Sснмітт S: Combination syndrome: A treatment approach. J Prosthet Dent 1985; 54: 664-671.

23. Shen K, Gongloff R: Prevalence of the combination syndrome among denture patients. J Prosthet Dent 1989; 62: 642-644.
24. Stahl SS, Wisan JM, Miller SC: The influence os systemic diseases on alveolar bone. J Am Dent Assoc 1952; 45: 277-283.

25. Tallgren A, LDS, Odont Dr: The continuing reduction of the residual alveolar ridges in complete denture wearers: A mixedlongitudinal study covering 25 years. J Prosthet Dent 1972; 27: 120-132.

26. The glossary of prosthodontic terms. J Prosthet Dent. 2005; 94: 10-92.

27. TolstunOv L.: Combination syndrome Symptomatology and Treatment. Compend Contin Educ Dent. 2011; 32: 62-66.

28. Tymstra N, Raghoebar GM, Vissink A, MeiJer HJ: Maxillary anterior and mandibular posterior residual ridge resorption in patients wearing a mandibular implant-retained overdenture. J Oral Rehabil. 2011; 38: 509-516.

\section{Markovics D, Szendi R, Vicko K, Rajnics Zs, Marada Gy, Radnai M}

\section{Incidence of combination syndrome based on the orthopantomograms made between 2009 és 2014 at the Department of Prosthodontics, University of Pécs, Hungary}

The treatment of patients having a completely edentulous maxillary arch and lower anterior teeth present is frequent in the dental practice. In these cases some specific changes can be detected in the oral cavity and on orthopantomograms. These signs were summarized and described first by Kelly (1972).

Aim of the study was to examine the presence of the specific signs of the combination syndrome among the patients between 2009 and 2014. With the help of the electronic patient registry system used by the University of Pécs, 319 patients were filtered who were diagnosed with anodontia code (K0000 International Classification of Diseases (ICD)) in the examined period. 220 patients' orthopantomograms were evaluated searching for specific symptoms of the combination syndrome. 34 patients had complete edentulous maxilla and anterior teeth in the mandible. 4 patients (11,7\%) showed the main sign of the combination syndrome, i.e. the maxillary anterior bone loss. Hypertrophy of maxillary tuberosity ( 9 cases, $26,4 \%$ ), extrusion of the lower anterior teeth ( 6 cases, $17,6 \%$ ) and great resorption of the distal mandibular ridge (16 cases, $47 \%$ ) was diagnosed on the X-rays. The clinical examination of three patients supported the radiological findings.

The combination syndrome was detectable, but the incidence rate was lower in this population in comparison with the data available in dental scientific publications.

Keywords: combination syndrome, bone absorption, maxillary tuberosity, hypertrophy, anterior teeth extrusion, implant 